\title{
THE IMPACT OF DIFFERENT ANTIEMETICS ON THE NAUSEA IN EARLY POSTOPERATIVE PERIOD AFTER LAPAROSCOPIC HOLECYSTECTOMY
}

Goran Marijanovic, Ljubica Radunovic

Department of Anaesthesiology, Clinical Center Montenegro, Podgorica, Montenegro

\section{UTICAJ RAZLIČITIH ANTIEMETIKA NA NASTANAK MUČNINE U RANOM POSTOPERATIVNOM PERIODU NAKON LAPAROSKOPSIKE HOLECISTEKTOMIJE}

Goran Marijanovic, Ljubica Radunovic

Odsek za anesteziologiju, Klinicki Centar Crne Gore, Podgorica, Crna Gora

\section{ABSTRACT}

Postoperative nausea and vomiting (PONV) is a patient-important outcome; patients often rate PONV as worse than postoperative pain. This clinical study was aimed to asses the efficiency of standard aniemetics administration separately or in combination in prevention of $P O N V$ in patients who underwent to the same surgical procedure - laparoscopic cholecystectomy. Also, this article could provide a novel information about the best choice for prevention and treatment of PONV. This study included 87 patients divided into four groups according to the postoperative phramacological treatment: First group was control group without treatment, Second group was group of patients with ondasetron treatment in postoperative period, Third group was group of patients with ondasetron+dexamethasone treatment, and fourth group was group of patients with dexamethasone treatment in postoperative period for nausea. PONV was distributed in Ondansetron+Dexamethasone group in the lowest percent (4.5\%), which means that this conbination of antiemetics was very effective. Than, Dexamethasone group was in relation with low incidence of PONV (14.3\%), and after that were Ondansetron and Control groups. Also smokers and males has lower incidence of $P O N V$, especially in combination with Ondansetron+Dexamethasone treatment.

The incidence of PONV is lower in male smokers patients who were underwent to combination of two antiemetics, ondansetron and dexamethasone compared to monotherapy and female nonsmokers. Preventive strategies for PONV must include risk stratification followed by prophylactic approach and also testing the newer antiemetics. Because of the high incidence of postoperative nause and vomiting as a patient-important outcome, the preventive strategies should be considered as serious condition which requires multimodal approach.

Keywords: Postoperative nausea and vomiting, antiemetics, Laparoscopic cholecystectomy.

\section{SAŽETAK}

Postoperativna mučnina i povraćanje (PONV) je za pacijenta važan ishod; pacijenti često PONV ocenjuju gorim od postoperativnog bola. Ova klinička studija imala je za cilj da proceni efikasnost standardne primene anemetike odvojeno ili u kombinaciji u prevenciji PONV-a kod pacijenata koji su bili podvrgnuti istom hirurškom zahvatu - laparoskopskoj holecistektomiji. Takođe, ovaj članak pruža nove informacije o najboljem izboru za prevenciju i lečenje PONV-a. Ovo istraživanje je obuhvatilo 87 pacijenata podeljenih u četiri grupe prema postoperativnom framakološkom tretmanu: prva grupa je bila kontrolna grupa bez lečenja; druga grupa je bila grupa pacijenata sa tretmanom ondasetrona u postoperativnom periodu; treća grupa je bila grupa pacijenata sa lečenjem tadasetron + deksametazon, a četvrta grupa je bila grupa pacijenata sa lečenjem deksametazonom u postoperativnom periodu za mučninu. PONV je raspodeljen u grupi Ondansetron + Deksametazon u najnižem procentu (4,5\%), što znači da je ova kombinacija antiemetika bila veoma efikasna. Zatim je grupa deksametazona bila u vezi sa niskom učestalošću PONV-a (14,3\%), a posle toga su bile Ondansetron i kontrolne grupe. Takođe, pušači i muškarci imali su nižu učestalost PONVa, posebno u kombinaciji sa lečenjem Ondansetron + deksametazonom.

Učestalost PONV-a manja je kod pacijenata pušačima koji su bili podvrgnuti kombinaciji dva antiemetika, ondansetrona $i$ deksametazona, u poređenju sa monoterapijom i ženama koje su nepušači. Preventivne strategije za PONV moraju uključivati stratifikaciju rizika praćenu profilaktičkim pristupom, a takođe $i$ testiranje novijih antiemetika. Zbog velike učestalosti postoperativne mučnine i povraćanja, kao važnog ishoda za pacijenta, preventivne strategije treba shvatiti kao ozbiljno stanje koje zahteva multimodalni pristup.

Ključne reči: Postoperativna mučnina i povraćanje, antiemetičari, laparoskopska holecistektomija.

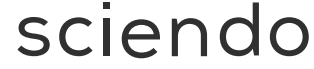

UDK: 615.243.6 616.366-089.85-06 Ser J Exp Clin Res 2021; 22 (2): 117-123 DOI: 10.2478/sjecr-2019-0019 


\section{INTRODUCTION}

Postoperative nausea and vomiting (PONV) is a patientimportant outcome; patients often rate PONV as worse than postoperative pain (1-3). PONV usually resolves or is treated without sequelae but may require unanticipated hospital admission and delay recovery room discharge $(2,3)$. In addition, vomiting or retching can result in wound dehiscence, esophageal rupture, aspiration, dehydration, increased intracranial pressure, and pneumothorax $(4,5)$.

The term PONV is typically used to describe nausea and/or vomiting or retching in the post-anesthesia care unit (PACU) or in the immediate 24 postoperative hours. Post-discharge nausea and vomiting (PDNV) refers to symptoms that occur after discharge for outpatient procedures (57).

The incidence of PONV varies with patient factors, anesthetic choices, and possibly the type of surgery (8-11). Patients factors which could induce PONV are patients with other diseases such as renal disease, history of PONV or motion sickness, age and chemotherapy-induced nausea and vomiting $(10,12)$.

On the second place are anesthetic factors which are usually associated with PONV such as anesthetic technique (11), volatile anesthetics and intravenous anesthetics (13), duration of anesthesia and opioid administration (14). Most of these drug factors are known and very rare today because by reducing the this known factors, we reduced the risk for PONV.

Previous study mentioned that type of surgery could be a very significant risk factor for PONV and studies of the effect of the type of surgery on the incidence of PONV have reported conflicting results (15-17). Literature data suggested that cholecystectomy, gynecologic, and laparoscopic procedures are associated with modestly increased risk of PONV compared with other general surgical procedures (16-19).

Laparoscopic cholecystectomy is the most commonly minimally invasive surgical procedure (11). The indication for this procedure is usually cholecystitis with or without stone. An incision is made on the navel, so the Hasson trocar or Verres needle is inserted through a small aperture. Insufflator is inserted into the abdominal cavity of CO2. In this way, the individual abdominal organs are separated from each other and the creator in which the organs can be seen and worked on with a special optical instrument. A special camera records and displays the image on the monitor. Complications include injuries to blood vessels, bile ducts, intestines and stomach. Direct postoperative complication is the onset of pain and vomiting, due to high pressure in the abdomen during interventions and due to instrument manipulation near the stomach.

In prevention of PONV there are well known strategies in clinical practice which are based on risk assessment and preventive evaluation of patinets characteristics, evaluating the individual patients's risk and evidence-based interventions when PONV occurs $(15,19)$. One of the used intervention is administration of aniemetics, where the usually are administried scopolamine patch, dexamethasone in dose of 4-8 mg intravenously after induction or ondansetron in dose of 4 mg intravenously at the end of the surgery (17). If nausea and vomitting occur in the post-anaesthesia care unit, administration of some other drug class of antiemetic could be effective, such as prochlorperazine in dose of 5-10 mg or droperidol in dose of $0.625 \mathrm{mg}$ (18). Other procedures for prevention and reducing the PONV risk include adequate hydration, intravenous dextrose solution administration and multimodal postoperative pain control (19).

This clinical study was aimed to asses the efficiency of standard aniemetics administration separately or in combination in prevention of PONV in patients who underwent to the same surgical procedure - laparoscopic cholecystectomy. Also, this article could provide a novel information about the best choice for for prevention and treatment of PONV.

\section{PATIENTS AND METHOD}

\section{Design of study}

This clinical opservational study was designed to evaluate patients in early postoperative period up to 24 hours after laparoscopic holecystectomy. All patients were observed before and after surgical intervention in Clinical Center Podgorica in Montenegro. All procedures were performed according to the Helsinski declaration and with Good Clinical Practice guidelines. All prcedures also were approved with guidelines of local institutional ethical committee.

\section{Patients and Protocol of study}

This study included 87 patients divided into four groups according to the postoperative phramacological treatment: First group was control group without treatment, Second group was group of patients with ondasetron treatment in postoperative period, Third group was group of patients with ondasetron+dexamethasone treatment, and fourth group was group of patients with dexamethasone treatment in postoperative period for nausea. Inclusion criteria were adult patinets with good general health, negative anamnesis regarding the previous PONV history and known socioepidemiological data.

Before inclusion in study, all patients were underwent internal and anesthesiology examination before surgical intervention, After 24 hours from the surgical procedure, we observed incidence and presence of nausea or vomitting in each patient. 


\section{Data analyses}

Results are presented as frequency and distribution in percent (\%). All data are presented in form of Tables. Analyses was done in SPSS version 22.0 statistical software.

\section{RESULTS}

\section{Demographic and anamnestic data of study population}

In study population female were present in $45.5 \%$ and male in $54.5 \%$ in Dexamethasone group, in $36.4 \%$ were present male gender and in $63.6 \%$ female in Ondansetron+Dexamethasone group, while the males were present in $34.8 \%$ and $33.3 \%$ in Ondansetron and Control group, as well as females in $65.2 \%$ and $66.7 \%$ in the same groups (Table 1 ). Also, female and male gender was differently distributed in groups with PONV, with predominantly present females in Control and Ondansetron groups with PONV (71.4\% and 100\%) (Table 2).

Regarding the distribution of the blood antigen in relation to group of patients, the most frequently was $\mathrm{O}$ antigen in all groups, than A antigen (31.8-57.1\%). Also, B and AB antigens were present in $9.1 \%$ to $21.7 \%$ in all groups (Table 1 ).

Table 1. Distribution of gender, blood antigen and smokers in study population

\begin{tabular}{|c|c|c|c|c|}
\hline \multirow{2}{*}{$\begin{array}{c}\text { All patients } \\
\text { Gender }\end{array}$} & \multicolumn{4}{|c|}{ Groups } \\
\hline & Dexamethasone & $\begin{array}{l}\text { Ondansetron + } \\
\text { Dexamethasone }\end{array}$ & Ondansetron & Control \\
\hline Male & 12 (54.5\%) & $8(36.4 \%)$ & $8(34.8 \%)$ & 7 (33.3\%) \\
\hline \multirow[t]{2}{*}{ Female } & $10(45.5 \%)$ & $14(63.6 \%)$ & 15 (65.2\%) & $14(66.7 \%)$ \\
\hline & Dexamethasone & $\begin{array}{c}\text { Ondansetron+ Dexa- } \\
\text { methasone }\end{array}$ & Ondansetron & Control \\
\hline A & 7 (31.8\%) & $8(34.6 \%)$ & 7 (30.4\%) & $12(57.1 \%)$ \\
\hline $\mathrm{O}$ & $11(50 \%)$ & 10 (45.5\%) & $8(34.8 \%)$ & $6(28.6 \%)$ \\
\hline B & $2(9.1 \%)$ & $2(9.1 \%)$ & $5(21.7 \%)$ & $2(9.5 \%)$ \\
\hline \multirow[t]{2}{*}{$\mathrm{AB}$} & $2(9.1 \%)$ & $2(9.1 \%)$ & $3(13.0 \%)$ & $1(4.8 \%)$ \\
\hline & Dexamethasone & $\begin{array}{c}\text { Ondansetron+ Dexa- } \\
\text { methasone }\end{array}$ & Ondansetron & Control \\
\hline Smokers & 5 (22.7\%) & $11(50 \%)$ & 10 (43.5\%) & $6(28.6 \%)$ \\
\hline $\begin{array}{l}\text { Non-Smok- } \\
\text { ers }\end{array}$ & 17 (77.3\%) & $11(50 \%)$ & 13 (56.5\%) & 15 (71.4\%) \\
\hline
\end{tabular}

Results are expressed as frequency (\%) in Dexamethasone, Ondansetron+Dexamethasone, Ondansetron and Control group 
Table 2. Distribution of PONV in study population and gender and smokers in PONV group of patients

\begin{tabular}{|c|c|c|c|c|}
\hline \multirow{2}{*}{\begin{tabular}{l}
\multicolumn{1}{c}{$\begin{array}{c}\text { Patients with } \\
\text { PONV }\end{array}$} \\
Incidence of \\
PONV
\end{tabular}} & \multicolumn{4}{|c|}{ Groups } \\
\hline & Dexamethasone & $\begin{array}{l}\text { Ondansetron + } \\
\text { Dexamethasone }\end{array}$ & Ondansetron & Control \\
\hline PONV & $3(14.3 \%)$ & $1(4.5 \%)$ & $5(21.7 \%)$ & $7(33.3 \%)$ \\
\hline \multirow[t]{2}{*}{ Non-PONV } & 18 (85.7\%) & 21 (95.5\%) & 18 (78.3\%) & $14(66.7 \%)$ \\
\hline & Dexamethasone & $\begin{array}{c}\text { Ondansetron+ Dexame- } \\
\text { thasone }\end{array}$ & Ondansetron & Control \\
\hline Male & $1(33.3 \%)$ & $0(0 \%)$ & $0(0 \%)$ & $2(28.6 \%)$ \\
\hline \multirow[t]{2}{*}{ Female } & 2 (66.7\%) & $1(100 \%)$ & $5(100 \%)$ & $5(71.4 \%)$ \\
\hline & Dexamethasone & $\begin{array}{l}\text { Ondansetron+ Dexame- } \\
\text { thasone }\end{array}$ & Ondansetron & Control \\
\hline Smokers & $1(33.3 \%)$ & $0(0 \%)$ & $2(40 \%)$ & $2(28.6 \%)$ \\
\hline Non-Smokers & 2 (66.7\%) & $1(100 \%)$ & $3(60 \%)$ & $5(71.4 \%)$ \\
\hline
\end{tabular}

Results are expressed as frequency (\%) in Dexamethasone, Ondansetron+Dexamethasone, Ondansetron and Control group

\section{Incidence of PONV in study population}

Generally, incidence of PONV in study population was $18.4 \%$, and 16 patients from 87 have PONV. The most frequently present PONV was in Control group (33.3\%), than in Ondansetron group (21.7\%), Dexamethasone group (14.3\%) and Ondansetron+Dexamethasone group (4.5\%) (Table 2).

Incidence of smokers in study population and in PONV patients

In Dexamethasone group smokers were present in $22.7 \%$, in Ondansetron+Dexamethasone group in $50 \%$, while in Ondansetron group were present in $43.5 \%$ and in $28.6 \%$ in Control group (Table 1). In relation to PONV, 33.3\% were smokers in dexamethasone group with PONV and $40 \%$ in Ondansetron group of patients with PONV, while there were no

\section{DISCUSSION}

This clinical study was aimed to asses the efficiency of standard aniemetics administration separately or in combination in prevention of PONV in patients who underwent to the same surgical procedure - laparoscopic cholecystectomy. Also, this article could provide a novel information about the best choice for prevention and treatment of PONV.

A variety of antiemetics acting via different mechanisms are used for prevention and treatment of PONV. In general, clinicians choose among these agents based upon side effect profile, personal experience, cost, and formulary considera- patinets with PONV in group with PONV which was treated with Ondansetron+Dexamethasone (Table 2).

Influence of the different pharmacological treatment on PONV incidence in study population

PONV was distributed in Ondansetron+Dexamethasone group in the lowest percent $(4.5 \%)$, which means that this conbination of antiemetics was very effective. Than, Dexamethasone group was in relation with low incidence of PONV (14.3\%), and after that were Ondansetron and Control groups (Table 2). Also smokers and males has lower incidence of PONV, especially in combination with Ondansetron+Dexamethasone treatment (Table 2).

tions (20-22). Previous study suggested that commonly used antiemetics reduce the risk of PONV by approximately 25 percent (23).

In our study, PONV was distributed in Ondansetron+Dexamethasone group in the lowest percent (4.5\%), which means that this conbination of antiemetics was very effective. Than, Dexamethasone group was in relation with low incidence of PONV (14.3\%), and after that were Ondansetron and Control groups (Table 2). Also smokers and 
males has lower incidence of PONV, especially in combination with Ondansetron+Dexamethasone treatment (Table 2).

Well, according to our result it is clear that antiemetics are very effective procedure in reducing the PONV incidence after the surgery. But, beside that we know that there is some problems with the effects of antiemetics. The absolute benefit of an antiemetics depends on the degree of baseline risk, for example, for a female nonsmoker patient with a history of motion sickness who requires opioids in postoperative period some of antiemetics would reduce a risk for PONV for a bigger procent than in contrast $(23,24)$.

We have founded that In Dexamethasone group smokers were present in $22.7 \%$, in Ondansetron+Dexamethasone group in 50\%, while in Ondansetron group were present in 43.5\% and in $28.6 \%$ in Control group (Table 1). In relation to PONV, 33.3\% were smokers in dexamethasone group with PONV and $40 \%$ in Ondansetron group of patients with PONV, while there were no patinets with PONV in group with PONV which was treated with Ondansetron+Dexamethasone (Table 2).

Definitely, smoking and gender are very important risk factors for development of PONV. Maybe the effects of drugs that acts on different receptors are additive rather than synergistic, and each added drug results in reducing the PONV risk (25).

In our study the most effective was ondansetron in combination with dexamethasone. The first-generation serotonin antagonists (ie, ondansetron, granisetron, and, outside the United States, dolasetron, ramosetron, and tropisetron) are equally efficacious for PONV at equipotent doses (relative risk [RR] 0.76 versus placebo) (26). All of these drugs have potential to prolong the electrocardiogram intervals, particularly the QT interval, and should be avoided for patients at risk for QTc prolongation. These agents are administered as a single dose at the end of surgery. Ondansetron is available as an orally disintegrating film (ODF) and as an orally disintegrating tablet (ODT), which are as effective as IV ondansetron $(27,28)$. The ODT may be useful for postdischarge administration and may be administered to children over the age of five.

On the other hand, dexamethasone as a glucocorticoid is effective as ondansetron for prevention of PONV (27), and it is the most common used and studied corticosteroid (28). Dexamethasone may be beneficial because of a direct antiemetic effect and by reducing postoperative pain and the need for postoperative opioids. Lower doses of dexamethasone may be required for PONV prophylaxis than for pain relief. A meta-analysis of 60 randomized trials with 6700 patients found that a dose of 4 to $5 \mathrm{mg}$ IV dexamethasone was as effective as 8 to $10 \mathrm{mg}$ IV for reduction of PONV (29). In contrast, two meta-analyses of studies comparing lower-dose $(<0.1 \mathrm{mg} / \mathrm{kg} \mathrm{IV})$ dexamethasone with higher doses $(>0.1$ $\mathrm{mg} / \mathrm{kg}$ ) found that higher doses were required for reduced opioid requirement $(30,31)$. A subsequent multicenter randomized trial including 1350 patients who underwent bowel surgery reported that a single postinduction dose of dexamethasone $8 \mathrm{mg}$ IV reduced the incidence of PONV at 24 hours and the need for rescue antiemetic for up to 72 hours.

Beside all these facts, administration of antiemetics, especially of ondansetron and dexamethasone should be individualized, becase these drugs have also adverse effects such as wound infection, decreasing cell counts, bone loss and other. In these cases, there are some other very effective antiemetics such as phenothiazines, which are effective in postoperative PONV but limited by their sedation and extrapyramidal effects $(32,33)$.

Also, literature dana suggested that metoclopramide and midazolam could be effective in PONV reducing (33) but less than ondansetron. Because of the adverse effects such as hypotension, tachycardia as well as sedation and postoperative delirium induced by midazolam, administration of these drugs are limited $(25,31)$.

Future studies and current investigations are oriented to the examination of cannabinoids which may be effective in treatment of chemotherapy-induced nausea and vomiting, but there is some suggestions regarding the PONV prevention (30).

Our study examined the effects of antiemetics on early nausea and vomiting in postoperative period (first 24 hours after surgery) and we concluded that combination of two antiemetics in male smokers were the most effective. But, stil lis unknown what is the best treatment for postdischarge nausea and vomiting (within 48 hours of discharge). Literature dana suggested that in these periods, the opioids are the most effective choice for reducing the nausea and vomiting incidence (29), but these assumptions must be examined in the future clinical studies.

Limitation of this study is small number of patients who were included and examined, so the future research shoud be on large study population with widely included variables which could interfere with incidence of PONV.

\section{CONCLUSION}

The incidence of PONV is lower in male smokers patients who were underwent to combination of two antiemetics, ondansetron and dexamethasone compared to monotherapy and female non-smokers. Preventive strategies for PONV must include risk stratification followed by prophylactic approach and also testing the newer antiemetics. Because of the high incidence of postoperative nausea and vomiting as a patientimportant outcome, the preventive strategies should be considered as serious condition which requires multimodal approach.

\section{CONFLICT OF INTEREST}

The authors declare that there is no conflict of interests. 


\section{REFERENCE}

1. Hill RP, Lubarsky DA, Phillips-Bute B, et al. Cost-effectiveness of prophylactic antiemetic therapy with ondansetron, droperidol, or placebo. Anesthesiology 2000; 92:958.

2. Bashashati M, McCallum RW. Neurochemical mechanisms and pharmacologic strategies in managing nausea and vomiting related to cyclic vomiting syndrome and other gastrointestinal disorders. Eur J Pharmacol 2014; 722:79.

3. Becker DE. Nausea, vomiting, and hiccups: a review of mechanisms and treatment. Anesth Prog 2010; 57:150.

4. Spiller R. Recent advances in understanding the role of serotonin in gastrointestinal motility in functional bowel disorders: alterations in 5-HT signalling and metabolism in human disease. Neurogastroenterol Motil 2007; 19 Suppl 2:25.

5. Horn CC, Wallisch WJ, Homanics GE, Williams JP. Pathophysiological and neurochemical mechanisms of postoperative nausea and vomiting. Eur J Pharmacol 2014; 722:55.

6. Bountra C, Gale JD, Gardner CJ, et al. Towards understanding the aetiology and pathophysiology of the emetic reflex: novel approaches to antiemetic drugs. Oncology 1996; 53 Suppl 1:102.

7. Kranke P, Eberhart LH, Toker H, et al. A prospective evaluation of the POVOC score for the prediction of postoperative vomiting in children. Anesth Analg 2007; 105:1592.

8. Apfel CC, Heidrich FM, Jukar-Rao S, et al. Evidencebased analysis of risk factors for postoperative nausea and vomiting. Br J Anaesth 2012; 109:742.

9. Sinclair DR, Chung F, Mezei G. Can postoperative nausea and vomiting be predicted? Anesthesiology 1999; 91:109.

10. Eberhart LH, Geldner G, Kranke P, et al. The development and validation of a risk score to predict the probability of postoperative vomiting in pediatric patients. Anesth Analg 2004; 99:1630.

11. Eberhart LH, Morin AM, Guber D, et al. Applicability of risk scores for postoperative nausea and vomiting in adults to paediatric patients. Br J Anaesth 2004; 93:386.

12. Rowley MP, Brown TC. Postoperative vomiting in children. Anaesth Intensive Care 1982; 10:309.

13. Palazzo M, Evans R. Logistic regression analysis of fixed patient factors for postoperative sickness: a model for risk assessment. Br J Anaesth 1993; 70:135.

14. Stadler M, Bardiau F, Seidel L, et al. Difference in risk factors for postoperative nausea and vomiting. Anesthesiology 2003; 98:46.

15. Apfel CC, Philip BK, Cakmakkaya OS, et al. Who is at risk for postdischarge nausea and vomiting after ambulatory surgery? Anesthesiology 2012; 117:475.

16. da Silva HB, Sousa AM, Guimarães GM, et al. Does previous chemotherapy-induced nausea and vomiting predict postoperative nausea and vomiting? Acta Anaesthesiol Scand 2015; 59:1145.
17. Apfel CC, Kranke P, Katz MH, et al. Volatile anaesthetics may be the main cause of early but not delayed postoperative vomiting: a randomized controlled trial of factorial design. Br J Anaesth 2002; 88:659.

18. Fernández-Guisasola J, Gómez-Arnau JI, Cabrera Y, del Valle SG. Association between nitrous oxide and the incidence of postoperative nausea and vomiting in adults: a systematic review and meta-analysis. Anaesthesia 2010; 65:379.

19. Tramèr M, Moore A, McQuay H. Omitting nitrous oxide in general anaesthesia: meta-analysis of intraoperative awareness and postoperative emesis in randomized controlled trials. Br J Anaesth 1996; 76:186.

20. Sneyd JR, Carr A, Byrom WD, Bilski AJ. A meta-analysis of nausea and vomiting following maintenance of anaesthesia with propofol or inhalational agents. Eur J Anaesthesiol 1998; 15:433.

21. St Pierre M, Dunkel M, Rutherford A, Hering W. Does etomidate increase postoperative nausea? A doubleblind controlled comparison of etomidate in lipid emulsion with propofol for balanced anaesthesia. Eur J Anaesthesiol 2000; 17:634.

22. Subramaniam K, Subramaniam B, Steinbrook RA. Ketamine as adjuvant analgesic to opioids: a quantitative and qualitative systematic review. Anesth Analg 2004; 99:482.

23. Bloomfield E, Porembka D, Grimes-Rice M. Avoidance of nitrous oxide and increased isoflurane during alfentanil based anesthesia decreases the incidence of postoperative nausea. Anesth Prog 1997; 44:27.

24. Vanacker BF. The impact of nitrous oxide on postoperative nausea and vomiting after desflurane anesthesia for breast surgery. Acta Anaesthesiol Belg 1999; 50:77.

25. Taylor E, Feinstein R, White PF, Soper N. Anesthesia for laparoscopic cholecystectomy. Is nitrous oxide contraindicated? Anesthesiology 1992; 76:541.

26. Ichinohe T, Kaneko Y. Nitrous oxide does not aggravate postoperative emesis after orthognathic surgery in female and nonsmoking patients. J Oral Maxillofac Surg 2007; 65:936.

27. Mraovic B, Simurina T, Gan TJ. Nitrous oxide added at the end of isoflurane anesthesia hastens early recovery without increasing the risk for postoperative nausea and vomiting: a randomized clinical trial. Can J Anaesth 2018; 65:162.

28. Apfel CC, Kranke P, Eberhart LH, et al. Comparison of predictive models for postoperative nausea and vomiting. Br J Anaesth 2002; 88:234.

29. Wallenborn J, Gelbrich G, Bulst D, et al. Prevention of postoperative nausea and vomiting by metoclopramide combined with dexamethasone: randomised double blind multicentre trial. BMJ 2006; 333:324.

30. Roberts GW, Bekker TB, Carlsen HH, et al. Postoperative nausea and vomiting are strongly influenced by postoperative opioid use in a dose-related manner. Anesth Analg 2005; 101:1343. 
31. Cheng CR, Sessler DI, Apfel CC. Does neostigmine administration produce a clinically important increase in postoperative nausea and vomiting? Anesth Analg 2005; 101:1349.

32. Yağan Ö, Taş N, Mutlu T, Hancı V. Comparison of the effects of sugammadex and neostigmine on postoperative nausea and vomiting. Braz J Anesthesiol 2017; 67:147.
33. Tramèr $M$, Moore $A$, McQuay $H$. Prevention of vomiting after paediatric strabismus surgery: a systematic review using the numbers-needed-to-treat method. Br J Anaesth 1995; 75:556. 